braziliensis. A PCR foi o melhor método na detecção da doença, ficando a Bx com os menores valores de detecção, somente não havendo significância estatística entre a IRM e a PCR. Na comparação entre a PCRRFLP e o sequenciamento, encontrou-se $61 \%$ de concordância entre os resultados, mostrando significância para PCR-RFLP para L. braziliensis.

Dıscussão: $O$ método PCR-RFLP representa menor custo e menor tempo de execução comparado ao sequenciamento de DNA, no que diz respeito aos reagentes e a equipamentos.

Conclusão: Concluímos que a IRM e a PCR são estatisticamente equivalentes como métodos subsidiários para o diagnóstico da LTA, lembrando que a IRM não tem tanto valor em área endêmica, e que a PCR-RFLP e o sequenciamento são equivalentes e eficazes na identificação das espécies de leishmania.

\title{
DEPARTAMENTO DE FOTOBIOLOGIA
}

\section{PP15 Importância do exame físico e raio $X$ no diagnóstico de artrite psoriásica e sua prevalência nos pacientes com psoríase no Hospital Universitário Evangélico de Curitiba (HUEC)}

\author{
AUTORES: Ataide D, Machado APB, Sandri C, Jordão JM, Vandresen N. \\ INSTITUIÇÃO: Hospital Universitário Evangélico de Curitiba - Curitiba, PR.
}

\begin{abstract}
INTRODUÇÃo: A artrite psoriásica é uma doença inflamatória associada com a psoríase da pele ou das unhas, com fator reumatóide negativo e ausência de nódulos reumatóides. Pode ser extremamente agressiva e deformante, deixando o paciente incapacitado para realizar funções do dia a dia. A prevalência populacional é muito variável; historicamente oscila entre 2,6-7\%; contudo, estudos recentes demonstram porcentagem de 23 a 30\% na população com psoríase. Em geral, ocorre em pacientes com doença severa e quanto maior gravidade, mais freqüente são os casos de artrite. Além disso, o acometimento ungueal apresenta maior relação com a presença da artrite. A psoríase ocorre anteriormente à artrite em $68 \%$ dos casos, no mesmo momento em $11 \%$ e após a artrite em $21 \%$ dos casos. 0 diagnóstico é de exclusão (artrite no exame físico, com fator reumatóide negativo e VHS elevado na presença de psoríase) e se realizado na fase inicial dá a chance para tratamento mais adequado, evitando complicações posteriores. Muitos indivíduos relatam artralgia na ausência da artrite e eles podem apresentar VHS elevado pela própria psoríase. 0 que realmente vai definir a presença da artrite é o exame físico adequado das articulações e o raio $\mathrm{X}$ demonstrando acometimento articular. É função do dermatologista fazer o diagnóstico de artrite psoriásica e acompanhar os pacientes com psoríase e artralgia, a fim de realizar o diagnóstico de artrite psoriasica em sua fase inicial.
\end{abstract}

Овлетіvo: Este estudo tem o objetivo de avaliar a prevalência de artrite psoriasica nos pacientes com psoríase de pele e/ou unha deste Serviço de Dermatologia.

Material e Métodos: Trinta pacientes com psoríase em acompanhamento neste Serviço foram submetidos a anamnese e exame físico minucioso. Foram questionados quanto alterações articulares, tempo e severidade de doença e comprometimento ungueal. Os que apresentavam queixas articulares seguiram investigação por meio dos seguintes exames complementares: hemograma, fator reumatóide, VHS, ácido úrico e Rx da articulação comprometida.

RESULTADO: A maioria dos pacientes referiu atralgia; contudo não apresentavam artrite no exame físico nem no raio $X$ da articulação acometida.

ConclusÃo: Os indivíduos com psoríase e queixas articulares devem ser acompanhados por meio de exame físico e raio $X$ seqüenciais, a fim de realizar diagnóstico preciso e na fase inicial da doença.

\section{DEPARTAMENTO DE IMAGEM}

PP16 Utilização da terapia ultrassônica de baixa intensidade na
redução da lipodistrofia ginecóide: uma terapia segura ou
risco cardiovascular transitório? - Um estudo pré-clínico

